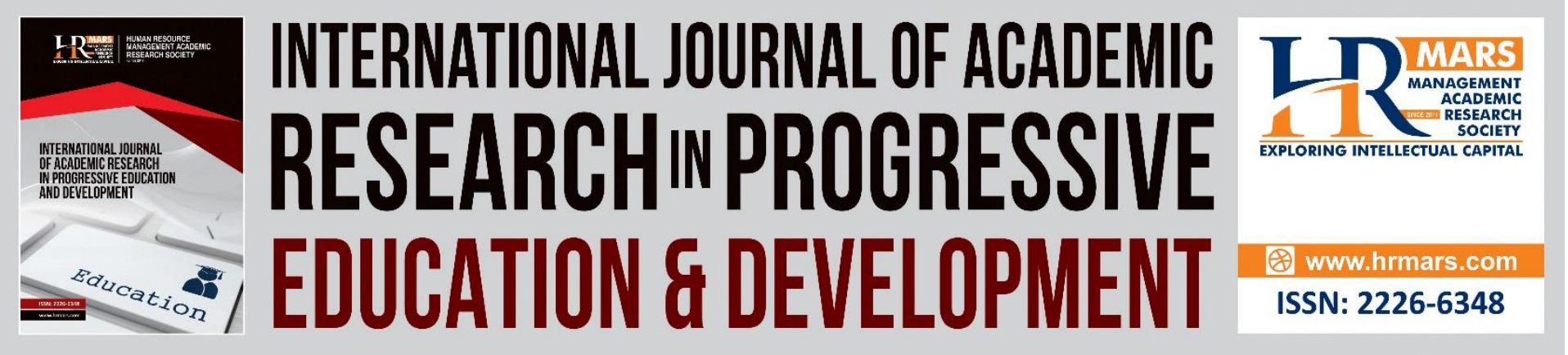

\title{
Reflective Practice: A Strategy for Improving Teaching Practice in Nigerian Colleges of Education
}

Ogunbameru Mercy Titilayo, Raymond Uwameiye

To Link this Article: http://dx.doi.org/10.6007/IJARPED/v1-i4/11969

DOI: 10.6007/IJARPED/v1-i4/11969

Received: 11 September 2012, Revised: 13 October 2012, Accepted: 19 October 2012

Published Online: 21 November 2012

In-Text Citation: (Titilayo \& Uwameiye, 2012)

To Cite this Article: Titilayo, O. M., \& Uwameiye, R. (2012). Reflective Practice: A Strategy for Improving Teaching Practice in Nigerian Colleges of Education. International Journal of Academic Research in Progressive Education and Development, 1(4), 71-83.

Copyright: (c) 2012 The Author(s)

Published by Human Resource Management Academic Research Society (www.hrmars.com)

This article is published under the Creative Commons Attribution (CC BY 4.0) license. Anyone may reproduce, distribute, translate and create derivative works of this article (for both commercial and non-commercial purposes), subject to full attribution to the original publication and authors. The full terms of this license may be seen at: http://creativecommons.org/licences/by/4.0/legalcode

Vol. 1(4) 2012, Pg. 71 - 83

http://hrmars.com/index.php/pages/detail/IJARPED

JOURNAL HOMEPAGE

Full Terms \& Conditions of access and use can be found at http://hrmars.com/index.php/pages/detail/publication-ethics 


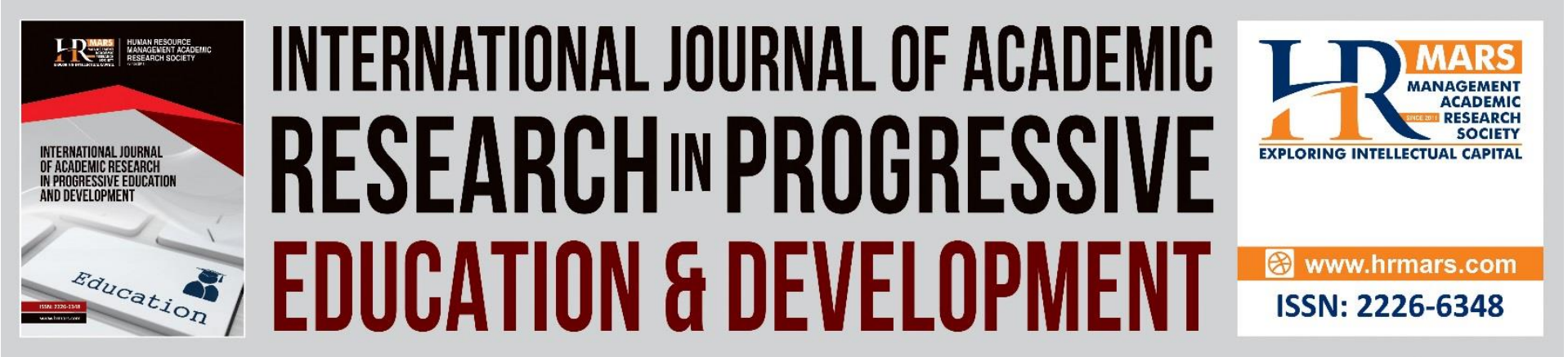

\title{
Reflective Practice: A Strategy for Improving Teaching Practice in Nigerian Colleges of Education
}

\author{
Ogunbameru Mercy Titilayo (Mrs)
}

Business Education Department, Adeyemi College of Education, Ondo, Ondo State, Nigeria

\author{
Prof Raymond Uwameiye \\ Ambrose Alli University, Ekpoma, Edo State Nigeria
}

\begin{abstract}
This study describes the place of reflective practice in quality assurance of teacher education professional development programme in Nigerian Colleges of Education. In relation to teaching practice, identified performance deficiencies were: poor student teachers' motivation to teach, low self efficacy, lack of acceptable preconception of teaching and learning and deficiency in transition of theory into practice in actual school setting. Among factors implicated for the deficiencies is the cooperating teachers' role expectation deficiencies, particularly weak relationship between student teachers and their cooperating teachers. Reflective practice potential was elucidated and recommended as improvement strategy for enhanced teacher professional development in Nigerian Colleges of Education.
\end{abstract}

\section{Introduction}

Teaching practice is a field experience course in Teacher Education Programme. Imogie (1990) defined teaching practice as a professional development exercise aimed at helping student teachers to bridge the gap between educational theories and practice. Maduabum and Abah (2004) defined teaching practice as a component of teacher education programme in which teacher trainees have the opportunity to put into practice all the teaching and classroom management theories they have acquired during the course of their studies with a view to attain professional competence. De-ville (2010) stated that teaching practice is an internship experience, a part of formative training process for pre-service teachers in skills exploration and enhancement. In the context of this paper teaching practice is a professional development course, a field experience for pre-service teachers' professional development. Teaching practice affords the student teachers opportunity to put into practice in actual classroom setting, theories and concepts learnt as curriculum contents in their academic programmes. As a course of study, it is characterized by the following features:

1. It is a vocational course, which is competency and performance based (Anikweze, Ojo and Maijaiga (2002). A form of internship for professional teachers, a statutory and 
mandatory professional requirement for entering into the teaching career (Federal Republic of Nigeria, National Commission for Colleges of Education, 2008).

2. As a skill development exercise, it is a kind of clinical therapy, designed to diagnose and remediate professional teachers' competence deficiencies (Ngidi and Sibaya, 2003).

3. It is designed as a feedback channel to generate information on the effectiveness or otherwise of a Teacher Education Programme.

4. Data gathering on student teachers' practicum assessment is based on a set of effective teaching indicators (Ngidi and Sibaya, 2003). The indicators are defined as practical teaching competences benchmark for qualify teachers at various levels of certification.

Teaching practice enhances pre-service teachers' professional development in the following ways:

1. Teaching practice provides the time and avenue for student teachers to acquire competences that are required in their teaching professional development (Ehinmetalor, 1990).

2. Practical teaching brings student teachers into a programme of cooperative and interactive guidance by experienced teachers (Young and Edwards, 2006).

3. Practical experience affords student teachers the opportunity to reflect on their own actions in the classroom and to acquire valuable skills, knowledge and attitude which are required in management of student learning experiences in the classroom (Imogie, 1990).

4. Teaching practice experience enhances pre-service teachers conceptualization of themselves as teachers. According to De Ville (2010), practical teaching affords student teachers the opportunity to reflect not just on matters associated with professional life and growth but also on who they are and are to become in the future.

Klob (1984) associated a higher level learning with reflection and conceptualization associated with active experimentation which teaching practice affords. De Ville (2010) asserted that experiential learning which practical teaching affords empowers the student teachers meaningful understanding of the concept of teaching, and ability to construct their own theories of teaching. De Ville (2010) further stated that teaching practice affords the trainees the opportunities to make personal observation of teaching and learning, formulate hypothesis, test their hypothesis and form their own theories of teaching and learning. Teaching practice is a means of effecting necessary emotional and professional changes in student teachers because as a learning method, it is experiential, student live through it. The author was of the opinion that on-site visitations by training institutions' staff such as College of Education Lecturers facilitate student teachers' cognitive as well as emotional adjustments.

Colleges of Education in Nigeria are tertiary institutions for teacher education and professional development. Colleges of Education basically award non-degrees, but highly specialized quality professional Diploma Certificates in Education known as Nigerian Certificate in Education (NCE) (Oyekan, 2000). NCE is the minimum professional teachers' qualification in Nigeria (Federal Republic of Nigeria, 2004). By implication, the College of Education is the first tier of tertiary institutions which run regular teachers' training and development programme. In relation to this paper, College of Education is a teacher education institution with curriculum structure in which teaching practice is a mandatory field 
experience for the award of Nigerian Certificate in Education. According to Anikweze, Ojo and Maijanga (2002), College of Education's NCE programmes are structured to strike a balance between the subject matter contents on one hand and between theories and practice on the other hand. The structural components of the curriculum contents are:

- General Studies in Education

- Educational Foundation Studies which consist of principles and practices of education.

- Studies related to students' intended field of teaching (one or two teaching subjects such as English, biology, business education, agriculture etc).

- Teaching Practice, and

- Research Project (Oyekan, 2000).

Various authors have identified weaknesses or flaws in the organization, implementation and evaluation of teaching practice exercise in Nigerian Teacher Education Institutions. In relation to student teaching practice, some of the problems identified are : lack of mentoring, practical teaching orientation and induction by cooperating teachers. (Ogonor and Badmus, (2006). Other weaknesses identified poor supervision by college base supervisors, subjective grading and poor feedback ( Maduabum and Abah, 2004). Lack of team work and coordinated work order by the training colleges and the cooperating centres (Ogonor and Badmus,2006).

Some of the effects of these deficiencies are:

1. Student teachers' poor motivation to practical teaching: De Ville (2010) shows that student teachers often see the education component of their professional training as being of secondary interest. They perceived their teaching subjects as being intellectually challenging and more closely aligned to their personal interest, hence, the trainees perceived no relevance of teaching practice to their interest except in its assessment import on their grade point average.

2. Student teachers misconception of teaching as transmission of knowledge (Harlin, Edwards and Briers, 2002).

3. Pre-service teachers lack of self efficacy and poor attitude to teaching as a career (Young and Edwards 2006). Casual observations by the authors of this paper as a teaching practice supervisor shows that many student teachers lack necessary ability to link theories learnt in class to classroom practice. Imogie (1990) attributed student teachers' deficiency in transition from theory to practice to inadequate preparation of students for such challenge due to a lack of model teaching practice laboratory in training colleges where student teachers should have been prepared adequately for such transition. In the opinion of Harlin, Edwards, \& Briers (2002), student teachers' experiences during teaching practice influence their attitudes and perceptions regarding their future careers as educators. Barnes and Camp (2002), Roberts and Dyer (2004) are of the view that it is the cooperating teachers and cooperating centres that impart the student teachers teaching experience the most; cooperating teachers foster unique teaching concepts and give support and encouragement to pre-service teachers, and the centres foster general supervisory climate and leadership abilities in the pre-service teachers (Martin and Yoder, 1985). Young and Edwards (2006) study on comparative study of student teachers' perceptions of important elements of student teaching experience before and after a twelve weeks field experience showed 
that cooperating teacher-student relationship was the most important perceived element in pre-service teacher professional development. It may be interesting to examine these deficiencies to ascertain the quality assurance of NCE programme.

Stoller (2003) define quality assurance as the degree to which an item or process meet or exceed the users requirements. In the view of Chesapeak (2004), It means the planned and systematic actions necessary to provide the confidence that a faculty, system or component will perform satisfactorily and safely in a service. Quality assurance in education refers to actions that educational institutions undertake to ensure that they provide required standard of education in order to provide quality manpower for national development (Nwizu, 2011). In relation to this study, quality assurance is the action put in place to improve student teacher practical teaching experience and to correct identified deficiencies in student teacher professional development.

Improvement according to Dalla (2001), means to make something or somebody better. To improve on something is to remediate the deficiencies in something or a circumstance (Robenson, 2000), The purpose of improvement is to make the related situation or event better. In relation to this study, improvement means the interventional strategies to remediate student teachers' learning deficiencies in teaching practice exercises in Nigerian Colleges of Education. The purpose is to make better students' professional learning experiences. Since certain weaknesses have been identified as it were, there is also the need to identify and try out possible remedial strategies

Brunner (1966) defined strategies as sequence of decisions purposely undertaken to achieve a goal. Ezeh (2008) defined a strategy as a process of doing something. Park and Osborne (2006) defined a strategy as a tool. In this study, a strategy is a goal directed activity or a pattern of behavior in teaching practice situation. It can also mean teaching and learning events which are designed to optimize student teachers professional competences in teaching practice field experience.

The purpose of this paper is to elucidate the potentials of reflective practice as teaching/ learning strategy which can improve student teachers' field experience in teaching practice exercise at Colleges of Education. The following are the main issues that are raised in this paper, and they include:

1. What is reflective practice in relation to students' professional teaching/learning experience?

2. Which strategies can be used to facilitate reflective practice in pre-service teachers professional learning experience?

\section{Concept of Reflective Practice}

Henderson (1996) defines reflective practice as an inquiry approach that emphasis ethics of caring, constructivist and creative problem solving. Reflective practice is an active and careful consideration of the basic assumptions and conclusion one holds in a direct experience that inform future actions (Nonlohy and Nosworthy, 2004). DeVille (2010) stated that reflection is a learning method which fosters meaningful learning through questioning and investigation. In relation to this discourse, reflective practice means the assessment of the 
underlying rationale for taking certain decisions in the process of teaching and learning. It also means the critical evaluation of the suitability or otherwise of decisions taken in relation to the effects of such decisions on student learning and teachers professional role expectations.

The purpose of reflection is to improve future decision making in subsequent practice teachings. This is in agreement with the opinion of Diezman and Walters (2006), who asserted that reflective practice is a means of ascertaining the effectiveness of teaching and learning activities. Schoon (1987) asserted that reflection in action carries functional potential of reconstruction of meaning, and that reflection in action and of action are means of developing professional capability for learning and problem solving. Stanley in Ogonor and Badmus (2004) stated that reflective teaching practice entails an ongoing examination of beliefs, and practices, their origins and their impacts on the teacher, the students and their learning process. Norsworthy (2008) reported that reflection is an element of metacognition. The author further asserted that reflection orientates learners towards self focus and self evaluation. To the author of this paper, self focus and self evaluation create in student teachers awareness of their personal cognitive motivational and behavioral states. The metacognitive awareness empowers student teachers to identify learning/teaching impediments and to device or adopt appropriate improvement strategies. Norsworthy (2008) validated this assertion in his research findings where $59 \%$ of the study respondents who were pre-service teachers in New Zeland found out that through reflective activities that student teachers' prior approaches to learning was a hindrance to their capacity to learn in manners which is reflective. The respondents also identified specific problems which constituted the hindrance as follows: their dependence on receiving note in form of handouts from their teachers, inability to think for themselves or get deeply engaged with the learning task due to their beliefs and dispositions to rote learning and memorization as strategies to pass examination, their test strategy was to give back to the teacher one right answer, to regurgitate the content of their teacher's note. Also the respondents reported a sense of inadequacy; apprehension and boredom, an emotional state which they found out hindered their reflective learning.

Highlighting the potentials of reflective practice, Bright (1996) asserted that reflective practice enhances learning processes. Reflective teaching practice according to Ashcroft (1992) involves the transformation of professional values and actions of the student teachers and that of others who the learner interact with.

Certain conditions are critical to the development of reflective practices. These include but not limited to the followings:

Prior Experiences (Bandura (1986): learners' methods of learning which they are conscious about and which they have stored and can retrieve as their learning schemas in their cognitive structures or long term memory.

Vicarious and Observation Learning: Vicarious and Observation Learning have powerful influence on formation of beliefs, values and opinions about the efficacy or otherwise of a learning experience (Smith in Loughran, 2002; Boekearts, 2002)), 
Preconceptual Knowledge and Beliefs of the Learners: (student teachers) (McGuigan and Weil, 2010): Preconception means the personal theory that a person holds that emanated from his/her learning experience. For instance, some teachers believe that teaching is transmission of timeless facts, that learning sole depends on teaching and that learning is acquisition of knowledge. These are likely preconceptions may significantly influence teacher and learners interactions in the classroom.

Mentoring: DeVille (2010) asserted that mentoring provides an informed experiential anchorage for reflective practices. The author explained that we do not learn significantly from experience but from the processing of experience. Block (2002) illuminated Deville's assertion by explaining that significant others, such as mentors provide encouragement which enliven learner's hope and optimism to undertake self reflection on personal experience. Drawing from Vygotsky's zone of proximal development, Rainkeri (2009) viewed knowledge construction in reflective practice as a co-creation through the interaction with others, particularly a capable others in guided reflection. The author further stated that the mentorship of experienced teachers by capable others deeply imprints a model of professional practice that has lifelong learning and professional development.

Other factors that impact significant influence on reflective practice are: relational trust, quality relationship, connected and associated emotional state. These are key determinants of the quality of reflective practice. such relationships foster a culture of supportive collaboration and constructive critical thinking (Vygotsky 1976). (De Ville, 2010). Young and Edwards (2006) Norsworthy (2008) showed that modeling pedagogy, using authentic teaching approaches, probing questions and assessment assist the development of reflective practice alongside with a sense of involvement and engagement in a participative community of learners and practice that engage in meaningful dialogue.

Skills required by trainees or learners to develop reflective learning practice include ability to communicate, exchange ideas, engage in self assessment, and team work (Deville, 2010) metacognitive skills of planning goal setting and monitoring (Parsons and Stephenson (2005), and critical thinking and collaborative skills (Norsworty, (2008)

\section{Strategies for Enhancing Reflective Practice}

According to Deville (2010), when considering strategies for enchancing reflective practice, particularly in developing a sense of professional self and belief structures, the following factors count :learning context, community of practice or learners and the influence of significant others. Accruing to Young and Edwards (2006), Academic staff (cooperating teachers) are primary significant others in molding student teachers' emergent professional lives as they are inducted into the teaching profession. Larrivee, (2000),John, (2004), reported that significant others' clearly thought out and well articulated system of personal beliefs, philosophical stances and professional values are essential conditions in mentoring self reflective student teachers. Fundamental beliefs arising from an individual mentors' world view regarding human development, learning and the nature of human being is core to one's capacity in self reflection.

Young and Edwards (2006) further stated that the depth and range of reflective experience (dimension of reflection) and the quality of positive relationship with a mentor have a high 
correlation with a student teacher's reflective practice (Nortworthy, 2008). Ellinor and Gerald in De-Ville, (2010) asserted that quality relationship, connection with significant others promotes necessary associated emotional state necessary for self reflection. Hong-Nam and Leavell(2011) identified emotional state of the learner as a prerequisite to ability to reflect on ones action. The authors asserted that there is a level of emotional stability needed to reflect on one's action. Ellionor and Gerald in DeVillie (2010) states that quality relationship and connection with significant others facilitate the necessary emotional state. The view corroborated Reiman (1999) view that knowledge construction in reflective practice is a cocreation through interactions with others particularly a capable others in guided reflection.

Contextual features that influence reflective practice are: Teachers pre dominant methods of teaching a particular subject domain, curriculum organization, organization of concepts in the recommended textbook, the type of learning approach being reinforced by teachers assessment and text book exercises and the nature of the subject for example science subject promote inquiry and discovery learning which require reflection. (DeVille, 2010).

Personal traits or aptitude that affect reflective practice of learners are: learners' personal goals, orientation and skill set, learners previous approach to learning, (Nortsworthy, 2008), learners preconception of learning, Yuruk(2005), learners emotional state, Hughes (2009), in the view of Hughes (2009) there is an emotional level needed to reflect on one's actions and if the learner has emotional deficit it may act as a barrier to the learners deeper reflection.

Reflective practice entails modeling meta cognitive activities and dialogue. DeVille (2010) asserted that when metacognitive skills are embedded into teaching of a course content, they promote the development, scaffolding and equipping of students with reflective practice. Klob (1984) asserted that reflection and conceptualization associated with active experimentation, intense practice and vicarious experimentation have high correlation with modeling.

Parson and Stephenson (2005), Hung-Namand Leavll(2011) research findings show that the integration of meta cognitive strategies of planning, monitoring, evaluating and adjusting learning performance are strategies to promote self reflection. The self reflective strategies eventually help students to find their own learning strategies that enhances their academic achievement most effectively (Kobayash and Lockee, 2008).

Roskos, Valenich and Risko (2001), stated that the quality of self reflection depend on the dimension of meta cognitive activities embedded in instruction and modeling the activities. To promote quality self reflection students should engage in activities that require them to:

Describe their learning process, report their observations, query some teaching and learning practices (activities), interpret, evaluate and critique some contextual and social political practices. This can be accomplished by the following strategies:

\section{Describe, Analyze, Theorize and Act (Data)}

Wilson (1999) describes DATA process as a means of helping critical reflection. It is a problem solving approach which stands for: 
Describe: describe the areas of practice which you discover needs improvement or change. It is the responsibility of the training colleges through close monitoring, college based supervisors' comments, action based research reports and recommendations and external moderators reports to form a clear opinion of lingering problems and identified impediments to effective learning in teaching practice exercises. The college bears the responsibility of carrying out action research at college level and in individual department to empirically describe the problem.

Analyse: Analyse the factors contributing to the problem area. Review of relevant literatures, focus group interviews, task analysis are relevant means of analyzing the problem area. This is to understand the underlying assumptions, beliefs and motives that are intervening or moderating students learning. The purpose of analyzes is to identify the composite factors and their likely relationships as it affect the problem area, and to enhance the formulation of testable hypothesizes as alternative ways of solving the problems. Test the hypothesizes to observe the effect on the identified problem. The process can be embedded into classroom instruction or implemented in micro teaching laboratory. Modeling of alternative teaching and learning strategies are helpful ways of testing formulated hypothesis. Objective observations give clear interactional relationships among related variables which lead to proposition of theory or principles. Peretemode (1995) described a theory as a principle, a statement which reasoning shows to be true.

Theorize. To theorize is to formulate propositions about fundamental truth or relationships which are to serve as guide to action, thinking, conduct or on the job practices that are to be consciously recognized and followed (Peretomode, 1995). Theory suggests possible ways to improve practice, and also the way forward.

Act: act on the theory by trying out the new prepositions to see how it works. Principles once propounded are not sacrosanct, they are subject to questioning, review, modification, refinement and are even discarded if they fail to serve the intended purpose. The purposes of principles or theories are to enhance efficiency and effectiveness as they serve as effective guidelines and procedures to help solve day to day problem of managing an entity (Peretemde, 1995). In relation to teaching practice exercise, the theories are to guide students' and faculty intelligent planning, organizing, controlling, decision making, communication, motivation, leading and evaluating the whole process of teaching and learning activities in classroom. the process can be summarized by the words of Braithwaite cited in Bordens and Abbott (2008) who proposed that the function of a science is to establish general laws/ principles covering the behavior of empirical events with which the science in question is concerned, it is to fuse together information concerning separate occurring events and to make reliable explanation and predictions about future, unknown events that occur in a variety of situations. To act on the theory, peer coaching can be used.

\section{Peer Coaching}

Peer coaching is a process in which two or more professional colleagues work together for a specific, pre determined purpose. . Peer coaching is non judgmental and non evaluative. The focus is on the collaborative development, refinement and sharing of professional knowledge and skills. Among pre service teachers, it is usually employed to improve as well as validate teaching performance and behaviors. The purpose may be to reflect on current practices, to 
expand, refine, and build new skills, to share new ideas, to teach one another, to conduct classroom observations or to solve classroom management related problems.

\section{Peer Coaching Procedure}

Peer coaching activities are cyclical in nature, each cycle comprises of three related activities referred to as a plan, teach and debrief cycle. Videotaping can be used to support reflection during several stages of the cycle. In peer teaching, teams are usually made up of two members one team member reflects on his or her pedagogy, while the other facilitates his reflection. The composition of peer mentors in peer teaching may vary.

\section{Plan}

To facilitate the planning, a semi structured set of questions are used to initiate the student teacher's thinking about the lesson. The team members brainstorm, raise questions to stimulate further ideas and discussions. The atmosphere is non judgmental enhancing the creative aspect of the planning activities. Working together exposes more pedagogical options. increases choices and encourages flexibility in practice.

Examples of planning questions are: how do you think you can teach this lesson? which teaching and learning principles are relevant to this lesson and how are they relevant? What are the important concepts in this topic and how are they related? What do you expect the students to already know about the concepts? What misconceptions do you think students have about these ideas? How will you address the misconception? How do you expect students to respond to your questions? which resources do you need to facilitate students learning? How do you expect student to respond to you question? Where would you like your students' thinking to be at the end of this lesson?

The purpose of the questions is to create awareness of the interactions of factors which promote proficiency in teaching and learning (Xie and Bradshaw (2010). knowledge of self, knowledge of content area, knowledge of teaching and learning principles, knowledge of students and the knowledge of context within school and the society are areas where the student teachers cognitive knowledge (Lai, 2010). The underlying assumption is that meaning is constructed when awareness is created by observing and gathering information to identify and implement hypothesis so as to explain a phenomenon and guide further actions and the implementation of the action.

\section{Teach}

In teaching the lesson, the team members strive to implement the questions, explanations, and discussions that were developed in the planning. They tries to recall and be prepared to address anticipated students' responses. Typically, plans are modified in the midst of teaching in response to actual students ideas, interpretations and questions, which inevitably vary from those anticipated when planning. The observing team members take note of critical aspects of the lesson to be reviewed during the debriefing. Such observations include:

The nature of student questions ; Are the questions procedural or conceptual oriented? Pattern of thought: Are students questions rhetorical or do they show understanding of relationships among concepts? 
Are the students processing the information and going beyond the information given or they are regurgitating teachers thought pattern and ideas?

How are misconceptions and mistakes addressed?

Is there enough wait time for student to think after posing a question?

Were the teaching resources adequate? Were they optimally utilized?

\section{Debrief}

Debriefing after the lesson is a reflective process which allows the team member who taught to think back on the experience of teaching. The observing team members facilitate the debriefing, as was done during the planning stage. The tone here again is non-evaluative. $A$ set of semi-structured questions, parallel to those used for planning is used to focus the students teachers thinking on significant aspects of the lesson and the contextual influential factors. This give rise to other questions which stimulate further ideas and discussion. Emphasis is on increasing the teaching team awareness of instructional decisions made, and their impact on the students, and how the questions enhanced or hindered the achievement of the instructional goals. Through this awareness the student teacher becomes more informed to effectively address similar issues in future lesson.

Examples of debriefing questions include the followings:

How do you think the lesson went? What worked and what did not work?

What will you do differently if you have the opportunity to teach the lesson again?

When __ happened, why did you decide to do Based on your experience what will you do in your next contact with the class?

\section{Videotaping}

Videotaping can be used to for reflecting on any of the various stages of the plan/ teach/debrief cycle. Examples of what worked and what did not work are found and carefully considered. A videotaped version gives teaching team the opportunity to engage in self observation, enabling them to take a more objective look at their teaching behaviors as well as notice unobserved student behaviors. The essence of coaching is to facilitate meta cognitive awareness and the use of appropriate strategies.

\section{Meta Cognitive Strategies}

According to Zimmerman (2000); Ogwo (2006); Eze and Onuigbo (2009); meta cognitive processes generally involve planning, monitoring and regulating. The most important metacognitive planning strategies identified by Kobayashi and Lockee (2008) are task analysis and goal setting. These activities help student plan their cognitive strategies use and organize information, and to activate prior knowledge related to the task of teaching certain concepts.

Commonly used monitoring strategies are self recording and self experimentation (Zimmerman, 2000), self experimentation is used when information obtained through monitoring is not sufficient(Kobayashi and Lockee (2008) students may systematically vary their performance and test different strategies to find the most effective one.

Regulating strategies in reflective teaching practice is in relation to using monitoring feedback to adjust or adapt strategy appropriate resources management. Resources management 
includes the control of study environment, time management and help seeking. These strategies are embedded in peer coaching and mentoring. Wong and Kerr (2009), research findings identified time management as a critical factor in professional development and a deficiency in student meta cognitive ability.

\section{Conclusion and Suggestions}

A review of relevant literatures and casual observations of student teachers' performance in the classroom revealed some performance deficiencies. Identified performance deficiencies are: student poor motivation to teach, low self efficacy, unconventional preconception of teaching and learning and inability of pre service teacher in transition of theory into practice. Among factors implicated for the deficiencies are the cooperating teachers' role expectation deficiencies particularly the relationship between the student teachers and the cooperating teachers.

In view of the potentials of reflective practice as a professional development strategy, it is hereby suggested that the reflective practice should the adopted as a strategy for improving the teaching and learning competences of teachers in training to adequately prepare them for their professional roles as teachers. It is should be incorporated to teaching practice exercise to develop in pre service teachers such skills as planning, decision making, team work, collaboration, communication, adaptability, analytical, problem solving and help seeking which are critical for survival in the twenty first century work setting (Wolters, 2010).

The purpose of reflective teaching practice to develop the transversal skills (Dettori and Persico, 2009). It is also a motivational technique to enhance student teachers self efficacy in teaching and to increase their self worth.

\section{References}

Ashcroft, K. (1992). Working togethero: Developing reflective student teachers. In Jonias \& C Biott, (eds), Working and Learning Together For Change. Philadelpia; Open University Press

Block, P. (2002), the answer to how is yes: acting on what matters.

Byrne, M., \& Willis, P. (2008). An exploration of tertiary accounting students prior approaches to learning outcome, International Journal Of Management Education,7(3), 34-46.

Chesapeak, B. (2004), Quality assurance. www.chesapeakebay.net4th Retrieval Date: June, 2012

De-Ville, P. (2010). Mentoring reflective practice in pre-service teachers. EABR \&ETLC Conference Proceeding: The voice of Austrailian Science Teachers reconstructing the mentoring provided by preservice Lecturers, especially in the development of professional reflective practice. Retrieval Date: $14^{\text {th }}$ August 2012

Ehiametalor, E. T. (1990). Teaching practice. Faculty of Education Seminar Series, University of Benin (Unpublished)

Ezeh, C. O. (2008). Effect of instruction in the use of meta-cognitive strategy of self monitoring on students' achievement in integrated science. An unpublished Ph.D Thesis: University of Nigeria, Nsukka.

Ezeh, U. N., \& Onuigb, L. N. (2009). Effects of instruction in meta-cognitive skills on science concepts, achievement and test anxiety on low achieving students in junior secondary schools. Review of Education, 20 (1) 
Federal Republic of Nigeria, National Commission for Colleges of Education (FGN, NCCE, 2008). Minimum Standards for NCE Teachers. Abuja: NCCE Press Abuja.

Federal Republic of Nigeria (2004). National policy on education: Lagos: NERDC press.

Harlin, J. F., Edwards, M. C., \& Briers, G. E. (2002). A comparison of student teachers' perceptions of important elements of the student teaching experience before and after completing an 11 week field experience. Journal of Agricultural Education, 43(3)

Hung-Nam, K., \& Leavll, A. G. (2011). Reading strategy instruction, metacognitive awareness, and self perception of striving college developmental readers. Journal of College Literacy and Learning 37

Imogie, I. (1990). Student practice teaching and the professional training of teachers in Nigeria: the need for a new strategy or the $21^{\text {st }}$ century. Faculty of Education Seminar Series $20^{\text {th }}$ anniversary1-15

Kobayashi, M., \& Lockee, B. (2008). Evidence based approaches for self regulated learning Revista Reginal De Investicacin Educativa, 5,33-43.

Martin, R. A., \& Yoder, E. P. (1985), clinical teaching analysis; A procedures foe supervising teachers. The Journal of American Association of Teacher Educators in Agriculture, 26(4)

McGuigan, N., \& Weil. (2010). Student preconception of introductory accounting: gallping over the biggest threshold of them all. Retieved from goggle on 8 June 2012.4

Nwizu, S. C. (2011). Implementating internal quality assurance strategies. International Journal of Education Research. 11(1)

Ogwo, B. A. (2006), Effects of metalearning instructional strategies on students' achievement in metalwork technology. Review of Education, 17(1).

Oyekan, S. O. (2000). Foundation of teacher education, Ibadan: Ben Quality Printers.

Reiman, A. J. (1999). The evolution of social role taking and guided reflection framework in teacher education: recent theory and qualitative synthesis of research. Teaching and Teacher Educatin 15(6).

Roberts, T. G., \& Dyer, J. E. (2004). Student teachers perceptions of the characteristics of effective cooperating teachers: A delphi study, Proceedings of The Southern Agricultural Education Research Conference

Schon, D. A. (1983). The reflective practitioner. New York, Basic Books.

Stoller, E. (2003). Quality assurance. www.stoller-eser.com.14th August, 2012

Wilson, G. (1999). Problem tools and techniques in problem solving model. Problem Solving And Decision Making. Britain: Pricewaterhouse Cooper Clays Ltd

Wing-Null, S. O., Cheng, M. H., \& Tsang, C. L. (1996). An impact of teaching practice : perceptions of teachers competence among student teachers, Journal of Primary Education 6(1\&2),

Young, R. B., \& Edwards, M. G. (2006). A comparison of student teachers' perceptions of important elements of the th3e student teaching experience before and after a 12 week field experience. Journal of Agricultural Education 47(3) 